\title{
Determination Yield To Maturity Bonds, Audit Quality As Moderators
}

\author{
Deri Yanto ${ }^{1}$, Darmansyah ${ }^{2}$ \\ ${ }^{1}$ Maksi, Faculty Economics and Business Universitas Pancasila, deri.yanto.indo@gmail.com \\ ${ }^{2}$ Maksi, Faculty Economics and Business Universitas Pancasila, darmansyahs155@yahoo.com
}

\begin{abstract}
Yield to maturity bonds are often used by investors in the effort to obtain mutual returns from investments and reduce the mismatch of the acquisition value obtained. Several factors that influence it such as exchange rates, inflation, BI interest rates, debt to equity ratio, and company size are also to examine the effect of audit quality in moderating the relationship. The purpose of this study was to determine how the influence of exchange rates, inflation, BI interest rates, debt to equity ratio, and company size also when moderated by audit quality. Audit quality as a moderator is taken as a means of increasing public trust, especially investors. The research sample is corporate companies that issued bonds on the Indonesia Stock Exchange in 2014 - 2018, as many as 103 companies with emissions that met the research requirements of 110 emissions. The method used is purposive sampling and multiple linear regression techniques. The results showed a correlation between the rate of return with yield to maturity, there were 3 significant influences namely the exchange rate moderated by audit quality, company size and company size moderated by audit quality. This research model based on the determinant test results was able to explain the dependent variable by $55.9 \%$ while $44.1 \%$ was explained by other dependent variables by $55.9 \%$ while $44.1 \%$ was explained by other variables.
\end{abstract}

Keywords: Exchange Rate, BI Rate, Debt to Equity Ratio, Size, and Yield to Maturity Bonds

Accepted: 07-07-2020, Revision: 23-12-2020, Published: 01-04-2020

\section{INTRODUCTION}

The level of fulfillment of companies sourced from the capital market has an important role in increasing the economic growth of a country where the capital market performs two functions at once, namely the economic function (economic) and financial function (financial) with the aim to increase economic growth (economics growth). From 2017 to 2018 predictions regarding the capital market will be a trend for the next three years that will provide yoy profits of between $5 \%$ to $15 \%$ which is good for the financial sector industry in Indonesia. Reportedly, if bond yields are high, the company is resistant to expansion. This can be seen in the yield of one of the SBNs whose main reference is the FR0064 series with a tenor of 10 years. The price correction has raised the benchmark 10- year yield by 221 basis points from the end of 2017 from $6.4 \%$ to $8.52 \%$. At present the average 12-month time deposit rate offered by 19 major banks in Indonesia is $4.96 \%$. The longer period of time it should not affect the company for expansion according to Suryani and Damayanti, 2015.

Basically, the capital market has an economic function due to the role of the capital market provider, namely to find those who have excess funds (investors) and those who need funds (investees). With the capital market, investors or capital owners as parties who have excess funds can invest these funds in the hope of getting a return (return) while the investee is a company that needs funds can use these funds for the benefit of the company's operations in developing investments without having to use funds from 
company operations. The capital market is said to have a financial function because the capital market has the opportunity and opportunity to obtain returns (return) for fund owners, according to the characteristics of investment (Darmadji and Tjiptono and
Fachrudin, 2012) . The purpose of the capital market to encourage the economy to grow and strengthen the economy of an $\mathrm{n}$ egara in terms of economic growth in its (economics growth).

Table 1 Yield to Maturity as Variabel Dependen

\begin{tabular}{ccccccc}
\hline Year & $\begin{array}{c}\text { Mean } \\
\text { YTM }\end{array}$ & $\begin{array}{c}\text { Mean } \\
\text { Kurs }\end{array}$ & $\begin{array}{c}\text { Mean } \\
\text { Inflasi }\end{array}$ & $\begin{array}{c}\text { Mean } \\
\text { SBI }\end{array}$ & $\begin{array}{c}\text { Mean } \\
\text { DER }\end{array}$ & Mean Size \\
\hline $\mathbf{2 0 1 3}$ & $11,45 \%$ & $11.777,00$ & $8,38 \%$ & $7.50 \%$ & $0,95 \%$ & $4.475 .595 .000,00$ \\
\hline $\mathbf{2 0 1 4}$ & $10,57 \%$ & $12.440,00$ & $8,36 \%$ & $7,75 \%$ & $0,98 \%$ & $5.367 .204 .000,00$ \\
\hline $\mathbf{2 0 1 5}$ & $10,10 \%$ & $13.795,00$ & $3,35 \%$ & $7,50 \%$ & $1,06 \%$ & $5.840 .822 .000,00$ \\
\hline $\mathbf{2 0 1 6}$ & $9,66 \%$ & $13.436,00$ & $1,97 \%$ & $6,50 \%$ & $1,29 \%$ & $7.521 .940 .000,00$ \\
\hline $\mathbf{2 0 1 7}$ & $9,36 \%$ & $13.548,00$ & $3,61 \%$ & $4,25 \%$ & $1,31 \%$ & $8.354 .237 .000,00$ \\
\hline $\mathbf{2 0 1 8}$ & $9,45 \%$ & $13.610,00$ & $3,13 \%$ & $5,75 \%$ & $0,75 \%$ & $6.805 .016 .000,00$ \\
\hline
\end{tabular}

Source: IDX (Data reprocessed) 2013-2018

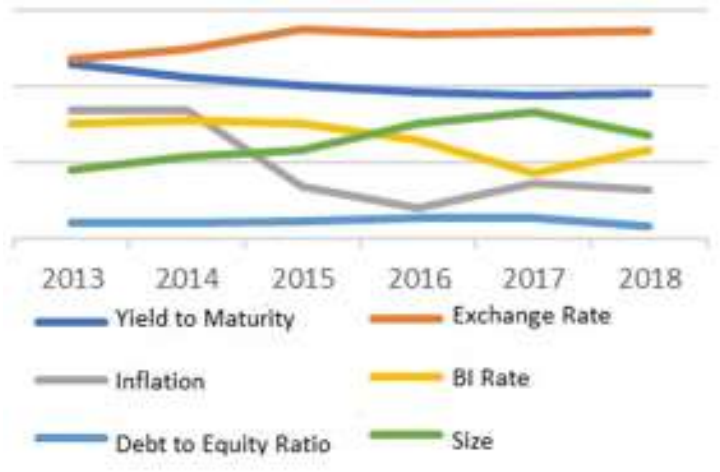

Source: IDX (Data reprocessed) 2013-2018

Figure 1. Grafik Yield to Maturity as Variabel Dependen

Based on the data in table 1.1 above, explain each indicator variable conducted to determine the gap analysis consisting of the dependent variable, namely yield to maturity, the independent variable consists of exchange rates, inflation, BI interest rates, leverage, and company size and for moderate variables namely audit quality (QA) cannot be displayed because it uses a system of 0 and 1 . Based on these data it can be concluded for the next three years that is 2016 - 2018 yield to maturity bonds has decreased.

The first shows the gap phenomenon, where in 2016 Mean yield to maturity for the next 3 years has decreased similarly only with mean inflation and SBI, it can be concluded that there is a positive correlation between mean yield to maturity with mean inflation and interest rates of Indonesian banks, it is inversely proportional to the mean Exchange Rate, DER and Size have a negative influence on yield to maturity.

Based on data in figure 1.1 above, shows a picture of trand of the issuers, exchange rates, inflation, interest rates on bank Indonesia, DER, and the size of the company, in the year 2013 until the year 2018, one variable is the quality of the audit will be excluded because the quality audit as a moderating variable. So basically the above variables become relevant as a means of testing and consideration of researchers to retest, a simple graph made review how far the index of each determining factor in taking 
investor policy in choosing the shade as investment advice that provides comfort, safety, and feed back in the form of returns received by investors.

I nvestor tend to be active in sorting and comparing based benefits and look of the risks that need to be observed from the data of financial statements. Law No. 12 of 2011 changes the acquisition and calculation system of investors based on trusted data sources so as to obtain the appropriate data, in (BAPEPAM-LK, 2011) Law no.12 of 2011 BAPEPAM-LK policy is transferred to OJK. Securities are making investors obtain source the latest data so look for returns and obtain the results, investors usually focuses on the data of bonds in the form of yield because of the data yields more detail in which investors can in the long term coordinated investments at regular intervals and may mem get a refund at the end of the maturity period in accordance the data they have forecashting.

As an investment instrument, yield changes (the level of bond yields obtained by investors will change over time. Changes in yields affect the level of bond market prices themselves. Therefore, both investors and issuers have a role to pay attention to bond price fluctuations and factors factors that influence it and one of the factors to be considered is interest rates that range from fluctuations (Hamid, Abdul, Rodon, Ahmad, W, Dewi Titi dan Hidayat, 2006). Each investment instrument must offer benefits, as well as bonds. Bond yields are revenue gains on investment received by investors and tend to be not fixed. There are several measures of yield are used by investors. each yield it measures the rate of return bonds from different perspectives. one measure of yield that is currently widely used is the yield to maturity. yield to maturity is ting kat return compound that would be acceptable if the investor bought the bonds at current market prices and holding the bonds to maturity. Investors will ask about the yield that will be obtained when buying bonds at a certain price. The negative relationship between the price and bond yield has a meaning, if the bond has meaning when the bond yield has increased, the bond price has decreased (Nabiu et al., 2006). Changes in the rate of return (yield) obtained by investors affect the market price of bonds. Therefore investors and issuers must always pay attention to price fluctuations and the parts that affect yield determination. Some previous studies that conducted yield research with its influence on the exchange rate were conducted (Tjandrasa, 2017)in his research showing the exchange rate is influential because it partially impacts on economic conditions and customer expectations, so it must be depreciated between the rupiah and dollar exchange rates. USD This is in line with research conducted by (Rahman \& Sam'ani, 2013) where the exchange rate on yield has an influence but tends to be negative, where if the exchange rate rises the bond price will rise and bond yield will be low or decrease. Since 1998 the issue of the exchange rate (exchange rate) is a feared risk, in that year Indonesia became worse off in a condition that caused the rupiah to weaken against the US dollar. The worst conditions that made the Indonesian people, especially students down the road to ask for justice for the economic conditions that fall due to exchange rates. Economic experts have a role to balance the economy and the emergence of a theory called aging, which uses the exchange rate as a means of consolidating and handling the exchange rate at that time.

Inflation shows the fall of the value of money in the eyes of the people at that time. There is also an inflation factor which is an indicator that cannot be denied. So the previous research that conducted research on the effect of inflation on bond yields gave research results which explained that inflation 
partially had no effect on bond yields on companies listed on the Indonesia Stock Exchange in the period 2010 to 2016 according (Listiawati \& Paramita, 2018). This is different from research conducted (Rahman \& Sam'ani, 2013; Saputra, 2014) which explains that the regression coefficient is positive and there is a significant influence between inflation and bond yields.

As for the previous research, Bank Indonesia's interest rates on bond yields from the following studies (Rahman \& Sam'ani, 2013; Tjandrasa, 2017) explain that interest rates have an effect on bond yields that are not proven, whereas according to research conducted (Nariman, 2017; Rahman \& Sam'ani, 2013; Saputra, 2014) explained that the interest rate on yield has a positive and significant effect. It can be concluded that interest rates increase bond yields.

The next variable is the leverage ratio used by previous research is a debt to equity ratio (DER) because investors see the ratio of the company's debt level that can affect yield. Some companies will determine the debt ratio as a minimization of the level of risk of return it will cause. Even yields will be affected by the DER. So in minimizing return returns, the research conducted by previous studies according (Nariman, 2017)(Hamid, Abdul, Rodon, Ahmad, W, Dewi Titi dan Hidayat, 2006) debt to equity ratio does not have a significant effect on yield, it differs in view of research according to (Listiawati \& Paramita, 2018; Noviana \& Solovida, 2018) where DER with yield has an influence but tends to be negative and significant to yield to maturity bonds. It is also demonstrated by the level of debt held perus a pany will increase the risk of default.

Company size is a scale in which the size of the company can be classified according to various ways, including: total assets, $\log$ size, market value of shares, and others. Basically the size of the company is only divided into 3 categories namely large, medium and small. Determination of the size of the company is based on the company's total assets (Machfoedz, 1994) .

Research conducted by (Listiawati \& Paramita, 2018) explains that company size on bond yield has no effect, this is contrary to the results conducted (Hapsari \& Artikel, 2013) showing that company size has a significant effect on YTM bonds. And according to (Nariman, 2017) that company size is influential but tends to be negative.

(Statement of Financial Accounting Concept (SFAC) No. 1, 1978) states that financial statements should provide useful information for investors or current creditors and the potential for making investment decisions. Basic accounting standards have concluded that relevant information about entities must support predictive capabilities. The main purpose of financial reporting is to invite investors to predict future cash flows.

The moderation variable used is audit quality, used as a refinement of these variables so as to improve the quality and value of the yield. According to (Nariman, 2017) explains the higher the quality of auditors, the higher the level of certainty about the company's financial condition that allows investors to get the best choice in investing.

Seeing the importance of bonds in the capital market sector is to reduce the level of risk received by investors as the owner of funds in an effort to reduce defaults that will harm investors. So the need for carefulness in checking the data in decisionmaking in choosing bonds in accordance with the objectives as a comparison and expectations in getting a return. 


\section{LITERATURE REVIEW}

Literacy in this study uses 2 basic theories that explain the tactics and their use. First, $s$ ignalling $t$ heory emphasize to all of the important information released by the company to the investment decision outside the company. Complete, relevant, accurate and timely information is needed by investors in the capital market as an analytical tool for making investment decisions. According to (HartonoMusakini, 2014), the information published as an announcement will provide positive sinyak for investors in making investment decisions, it is expected that the market will be reaction at the time of the announcement can be accepted by the market. Secondly, contracting theory or contract theory is a binding agreement between two parties or more individuals, groups, entities, up diplomatic. The purpose of the agreement is expected to get positive results in the form of profits for both parties who execute the agreement. With a favorable agreement because of the lack of risk, investors are interested in investing their capital in an investment, tend to the capital market. A detailed agreement will peg into the profits as an incentive for company managers to present good financial data and manage it well. According to (Watts \& Zimmerman, 2006) explain the empirical evidence of the benefits of accounting is relevant information on cash flow perus a pany current and future ultimately be linked to the perus a pany (firm value). On the other hand accounting benefits are part of the accounting aspects and are known as cues or references in the decision making process and policies are important for the makers and users of financial statements and if due to widespread accounting earnings (Francis \& Schipper, 1999; Neimark, 1994; Vose, 1996). This is in accordance with what investors want in getting a return from a bond, investors hope that the engagement has specific advantages for itself and can benefit from the bonds in the form of cupon.

\section{Bonds}

Bonds are fixed income securities traded in communities where the issuer agrees to pay a fixed amount for a certain period of time and will repay the principal amount at maturity (Ang \& Sherris, 1997). Bonds are basically letters of acknowledgment of loans for loans received by companies issuing bonds from the investor community. The term of the bonds has been set and accompanied by rewards interest amount and time of payment has been determined in agreement (Sunariyah, 2013).

\section{Bond yield}

Bond yield is the most important factor for investors to consider when buying bonds as an investment instrument. Yield which is a return on the yield from bond investments expressed in percentages (Samsul, 2006). Yield to Maturity (YTM) can be interpreted as a compound rate of return that investors will receive if they buy bonds at this market price and hold the bonds until maturity (Ibrahim, 2004) . Bonds in the Indonesian capital market and how to calculate the total return on bond investments used for portfolio analysis.

\section{Yield to maturity}

Yield to maturity (YTM) is a yield measure that is widely used because the yield reflects returns with compounded rates of return expected by investors, if the two assumptions required can be fulfilled. The first assumption is that investors will hold the bonds until maturity. The value obtained if the first assumption is met is often called yield to maturity (YTM). The second assumption is that investors reinvest income derived from bonds at the level of YTM generated, along with the second equation: 
$\mathrm{P}=\sum_{t=1}^{2 n} \frac{\frac{\mathrm{C} i}{2}}{\left(1+\frac{Y T M}{2}\right)^{t}}+\frac{P p}{\left(1+\frac{Y T M}{2}\right)^{2 n}}$

Information :

$\mathrm{P}=$ current bond price $(\mathrm{t}=0)$

$\mathrm{N}=$ number of years until the bond maturity

$\mathrm{Ci}=$ coupon payments for $i$ bonds annually

$\mathrm{YTM}=$ yield to maturity

$\mathrm{Pp}=$ par value of bonds

\section{Exchange Rates (Exchange Rates)}

According to Black, (Black et al., 1992) " an exchange rate is defined as the amount of one currency that can be exchanged per unit of another currency, or the price of one currency in items of another currency ( exchange rate) is the amount of a currency which can be exchanged with a currency of another country, or the price of a currency calculated with another country's currency). " $\mathrm{N}$ use values the exchange is the price of the rupiah against the currencies of other countries. So the rupiah exchange rate is the value of a currency that is translated into another country's currency.

\section{Bank Indonesia Interest Rates}

According to Kern and Guttman (1992) as described by (Laksmono $\mathrm{R}$ et al., 2003) considers the interest rate to be a price and as with other prices, the interest rate is determined by the interaction between demand and supply (Laksmono $\mathrm{R}$ et al., 2003). Interest rates are one of the variables in the economy that is most often observed because it has a broad impact. Interest rates have a direct influence on people's lives and have an important impact on the health of the economy. Changes in interest rates will affect individuals, business enterprises and some economic sectors. If interest rates rise, bond prices will decline, and vice versa (Black et al., 1992; Mishkin, 2007) states that changes in interest rates will greatly affect the financial decisions of investors, as well as

ISSN: 2355-0295, e-ISSN: 2528-2255

http://ejournal.bsi.ac.id/ejurnal/index.php/ecodemica other financial institutions. Between interest rates and the value / price of a security have a close relationship (Mishkin, 2007).

\section{Debt to Equity Ratio}

Debt to Equity Ratio (DER) Investors need to know the health of the company through a comparison between own capital and loan capital. If own capital is greater than loan capital, then the company is healthy and not easy to go bankrupt. Debt to equity ratio can also provide an overview of the capital structure owned by the company so that it can be seen the level of unpaid debt risk (Suharti \& Sirine, 2012). Debt to Equity Ratio can be calculated using the formula below. Leverage ratio analysis, also called solvency, aims to provide an overview of a company's ability to meet its obligations, both short and long term. In the banking industry, solvency ratios are used to measure the ability of banks to meet their debt to equity ratio. DER is used to measure the ability of banks to cover part or all of their debts, both shortterm with funds from their own capital according to (Kuswadi, 2005).

\section{Company Size}

According to (Sawir, 2012), company size is expressed as a determinant of financial structure in almost every study for different reasons, including: (1) Company size can determine the level of ease of a company obtaining funds from the capital market. Small companies generally lack access to organized capital markets, both for bonds and shares. Even if they have access, the launch fee from selling a small number of securities can be a barrier. If the issuance of securities can be done, the securities of small companies may be less marketable so it requires pricing so that investors get results that provide significantly higher returns. (2) Firm size determines bargaining power in financial contracts. Large companies can usually choose funding from various forms of 
debt, including special offers that are more profitable than those offered by small companies. The greater the amount of money used, the more likely the possibility of making a contract designed in accordance with the preferences of both parties instead of using a standard debt contract. (3) There is the possibility of the effect of scale in costs and returns making a larger company can get more profit. In the end, the size of the company is followed by other characteristics that affect the financial structure. Other characteristics such as companies often do not have special staff, do not use financial plans, and do not develop their accounting systems into a management system.

\section{Audit Quality}

(Agoes, 2017) states that auditing provides added value to the company's financial statements, because the public accountant at the end of the examination provides an opinion on the reasonableness of the financial statements. The auditor is one mechanism to be able to control management behavior to act in their own interests. The quality of a job is very closely related to what a person does in his work and the results of his work. Two public accounting reports produced from the same accounting firm can have different qualities. States that the attributes that must be possessed by qualified auditors include 12 things: experienced, expertise in the client industry, responsive to client needs, having technical competence, Independent, exercising due care, commitment to quality , involving KAP partners / managers in audit assignments, carrying out field work properly, interacting with client audit committees, having high ethical standards and accounting and auditing knowledge, and being skeptical in audit assignments. Empirical evidence has proven that there are differences in audit quality conducted by KAP. The size of KAP in this case is divided into large KAP (big 4 accounting firms) and small KAP ( Non big 4 accounting firms). The difference is based on the number of clients owned, the number of colleagues / members who joined, and the total revenue earned in one period. The bigger a KAP, the more resources it has. Larger resources are expected to have a relationship with audit quality that is also good.

\section{RESEARCH METHODS}

The selection of variables used some basic requirements or assumptions that must be met when using the Pearson bivariate to test each variable whether the selected variable has a significance level, namely conformity to the wishes of the researcher. The type of data used in this research is secondary data, the data source is obtained from the Indonesia Stock Exchange (IDX), from additional detailed explanations obtained through the Indonesia Capital Market Directory (ICMD), Indonesia Central Security Depository (KSEI). The Indonesian Bond Pricing Agency (IBPA), and historical sources from BAPEPAM (old BAPEPAM), and the website of Bank Indonesia. The sample collection method used was nonparticipant observation. Participant observation is an observation that involves the researcher to observe the object under study, non-participant observation, that is, an observation in which the researcher is not directly involved with the subject under study.

\section{DISCUSSION}

Based on the results of the bivariate Pearson variable, the above variables are worthy to be tested again. D ata used in this research is secondary data that is quantitative, in the form of data exchange, inflation, interest rates BI, DER , company size, quality audit and yield to maturity of the bonds. Data sources were obtained from the Indonesia Stock Exchange (IDX), from additional detailed explanation obtained through the Indonesia Capital Market Directory (ICMD), the Indonesia Central Security Depository (KSEI), the Indonesian Bond Pricing Agency (IBPA), the historical source of BAPEPAM (BAPEPAM years old) , and Bank Indonesia website . 
The population in this study are all listed corporate bonds traded on the Indonesia Stock Exchange from 2014 to 2018 with a total of 103 companies issuing bonds with a total of 414 emissions after being sorted according to criteria, to 110 emissions.

Table 2 List Of Criteria

\begin{tabular}{ll}
\hline Criteria & Amount \\
\hline $\begin{array}{l}\text { Companies listed on the Indonesia Stock } \\
\text { Exchange in 2014-2018 }\end{array}$ & 602 \\
\hline $\begin{array}{l}\text { Companies that issue bonds on the Indonesia } \\
\text { Stock Exchange in 2014-2018 }\end{array}$ & 103 \\
\hline $\begin{array}{l}\text { Overall Bond Issuance on the Stock Exchange in } \\
\text { 2014-2018 }\end{array}$ & 414 \\
\hline $\begin{array}{l}\text { Bond issuance in IDX in 2014-2018 that does not } \\
\text { meet keriteria }\end{array}$ & 304 \\
\hline Total units (5 years of observation) & $\mathbf{1 1 0}$ \\
\hline $\begin{array}{l}\text { Source: Data processed } \\
\text { Classic Assumption Test Results }\end{array}$ \\
\hline
\end{tabular}

Testing of classical assumptions is intended to find out and ensure that the data used in research is free from all problems of classical assumptions.

\section{Normality Test Results}

The normality test aims to test whether in the regression model, confounding or risk variables have a normal distribution. To test the normality of this data used the Kolmogorov-Smirnov one sample statistical test with the rule of decision if significant more than $\alpha=0.05$, it can be said that the data is normally distributed. Kolmogorov-Smirnov test one sample calculation results can be selected $\mathrm{t}$ :

Tabel 3

Kolmogorov-Smirnov Test One-Sample Test Results

One-Sample Kolmogorov-Smirnov Test

\begin{tabular}{llr}
\hline $\mathbf{N}$ & & $\mathbf{1 1 0}$ \\
\hline $\begin{array}{l}\text { Normal } \\
\text { Parameters }\end{array}$ & Mean & .0000000 \\
\hline & Std. Deviation & .80948623 \\
\hline $\begin{array}{l}\text { Most Extreme } \\
\text { Differences }\end{array}$ & Absolute & .073 \\
\hline & Positive & .073 \\
\cline { 2 - 3 } & Negative & -.065 \\
\hline $\begin{array}{l}\text { Test Statistic } \\
\begin{array}{l}\text { Asymp. Sig. } \\
\text { (2-tailed) }\end{array}\end{array}$ & .073 \\
\hline
\end{tabular}

Source: Data Processed

Based on the results of the output above the significance value (Asymp. Sig. 2tailed) has a risk value that is equal to 0.200 $\geq 0.05$, it can be concluded that all variables tested were normally distributed. Thus it can be concluded that the residual value of this research data is normally distributed.

\section{Multicollinearity Test Results}

Multicollinearity test aims to test whether the regression model found a correlation between independent variables. To find out the source of multicollinearity-free regression model that is by looking at the tolerance value or Variance Inflation Factor (VIF). If the tolerance value $>0.1$ or with a VIP value $<10$ then it is declared free of multicollinearity. The value of Variance Inflation Factor (VIF) and the following tolerance figures.

Table 4

\begin{tabular}{|c|c|c|c|}
\hline & Multicolin & $\begin{array}{l}\text { arity Test } \\
\text { Coefficients }\end{array}$ & sults \\
\hline Model & & Tolerance & VIF \\
\hline 1 & $\begin{array}{l}\text { Exchange } \\
\text { Rate }\end{array}$ & .637 & 1.569 \\
\hline & $\begin{array}{l}\text { Exchange } \\
\text { Rate_QA }\end{array}$ & .040 & 24.877 \\
\hline & Inflation & .252 & 3.975 \\
\hline & Inflation_QA & .119 & 8.409 \\
\hline & SBI & .148 & 6.743 \\
\hline & SBI_QA & .031 & 31.861 \\
\hline & DER & .167 & 5.971 \\
\hline & DER_QA & .111 & 8.996 \\
\hline & Size & .000 & 5276.901 \\
\hline & Size_QA & .000 & 5325.373 \\
\hline
\end{tabular}

Source: Data Processed

Based on the table above it can be seen that each VIF is as follows:

a. The VIF value for the exchange rate has a value of $1.569<10$ which means that the exchange rate does not find a multicollinearity relationship. 
b. VIF Value The exchange rate moderated by audit quality ( Exchange Rate_QA ) has a value of 24.87> 10 which means that inflation is found to have a multicollinearity relationship.

c. VIF Value Inflation has a value of 3.97 $<10$ which means that inflation is moderated by audit quality and there is no multicollinearity relationship.

d. VIF Value Inflation moderated by audit quality (Inflation_QA) has a value of 8.40 $<10$, which means that the $\mathrm{BI}$ interest rate does not reveal any multicollinearity relationship.

e. Value VIF S uku interest BI (SBI) has a value of $8.40<10$, which means that the central bank interest rate did not find any relationship multikolinearitas.

f. VIF Value BI interest rate moderated by audit quality (SBI_QA) has a value of 31.86> 10 which means that BI interest rate moderated by audit quality found a multicollinearity relationship.

g. VIF DER value has a value of $5.97<10$ which means that DER does not find any multicollinearity relationship.

h. VIF DER value is moderated by Audit Quality (DER_QA) has a value of 8.99 $<10$ which means that DER is moderated by audit quality, there is no multicollinearity relationship.

i. VIF Value The size of the company ( Size ) has a value of 5,276.90> 10 which means that the size of the company found a multicollinearity relationship.

j. VIF Value The size of the company is moderated by audit quality (Size_QA) has a value of 5,325.37> 10 which means that the size of the company is moderated by audit quality found a multicollinearity relationship.

\section{Heteroskedsticity Test Results}

Heteroscedasticity test conducted to determine whether the regression mode occurs inequality variance of risidua 1 an observation to another observation. If the variance from one observation residual to another observation is fixed then it is called homokedastisitas and if different is called heterokedastisitas. The results of heteroscedasticity using the Glajser test can be seen the statistical results as follows:

Table 5 Heteroscedastic Test Results

\begin{tabular}{|c|c|c|c|c|c|c|}
\hline \multirow{2}{*}{\multicolumn{2}{|c|}{$\begin{array}{l}\text { Mod } \\
\text { Model }\end{array}$}} & \multicolumn{2}{|c|}{$\begin{array}{c}\text { Unstandardized } \\
\text { Coefficients }\end{array}$} & \multirow{2}{*}{$\begin{array}{c}\text { Standardized } \\
\text { Coefficients } \\
\text { Beta }\end{array}$} & \multirow[t]{2}{*}{$\mathbf{t}$} & \multirow[t]{2}{*}{ Sig. } \\
\hline & & B & $\begin{array}{l}\text { Std. } \\
\text { Error }\end{array}$ & & & \\
\hline 1 & (Constant) & -3.630 & 1.740 & & 2.086 & .040 \\
\hline \multicolumn{2}{|c|}{ Exchange Rate } & .000 & .000 & .317 & 2.912 & .004 \\
\hline & $\begin{array}{l}\text { Exchange } \\
\text { Rate_QA }\end{array}$ & $\begin{array}{r}8.113 \mathrm{E}- \\
5\end{array}$ & .000 & -.759 & $\begin{array}{r}- \\
1.749\end{array}$ & .083 \\
\hline & Inflation & -.069 & .075 & -.158 & -.913 & .364 \\
\hline & Inflation_QA & .107 & .087 & .310 & 1.229 & .222 \\
\hline & SBI & .025 & .104 & .054 & .237 & .813 \\
\hline & SBI_QA & -.012 & .113 & -.053 & -.108 & .915 \\
\hline & DER & -.092 & .040 & -.492 & 2.314 & .023 \\
\hline & DER_QA & .106 & .045 & .615 & 2.356 & .020 \\
\hline
\end{tabular}




\begin{tabular}{lrrrrr}
\hline Size & - & .000 & -1.694 & -.268 & .789 \\
& $2.203 \mathrm{E}-$ & & & & \\
9 & & & & & \\
\hline & $2.148 \mathrm{E}-$ & .000 & 1.660 & .261 & .794 \\
9 & Size_QA & & & &
\end{tabular}

The requirement for a heteroscedasticity-free data from the glacier test is if the significance of each independent variable> 0.05 . Based on the table above then:

a) The exchange rate has a significance value of $0.004<0.05$ then the data is considered to have heteroscedasticity.

b) Exchange rates are moderated by the quality of the audit (Exchange Rate_QA) has a significance value of $0.083>0.05$, then the variable is considered to have no heteroscedasticity.

c) Inflation has a significance value of $0.364>0.05$ then the variable does not have heteroscedasticity.

d) Inflation is moderated by audit quality (Inflation_QA) has a significance value of $0.222>0.05$ then the variable does not have heteroscedasticity.

e) BI interest rate (SBI) has a significance value of $0.813>0.05$, so the variable does not have heteroscedasticity.

f) BI interest rates are moderated by audit quality (SBI_QA) having a significance value of $0.915>0.05$, so the variable does not have heteroscedasticity.

g) DER has a significance value of 0.023 $<0.05$, so the variable has heteroscedasticity.

h) DER is moderated by audit quality (DER_QA) has a significance value of $0.020<0.05$, it can be concluded that the variable has heteroscedactivity.

i) Size of the company (Size) has a value of $0.789>0.05$ then the variable does not have heteroscedasticity.

j) The size of the company is moderated by audit quality (Size_QA) has a significance value of $0.794>0.05$ then the variable does not have heteroscedasticity.

\section{Feasibility Model (R 2)}

The determinant coefficient is used to determine the ability of the independent variable in explaining the dependent variable. Here are the results of the determinant coefficient:

Table 6 Determinant Coefficient Results

\begin{tabular}{lcccc} 
& \multicolumn{3}{c}{ Model Summary } \\
\hline Model & $\mathbf{R}$ & $\begin{array}{c}\text { R } \\
\text { Square }\end{array}$ & $\begin{array}{c}\text { Adjusted } \\
\mathbf{R}\end{array}$ & $\begin{array}{c}\text { Std. } \\
\text { Error of } \\
\text { the } \\
\text { Square } \\
\text { Estimate }\end{array}$ \\
\hline $\mathbf{1}$ & $.748^{\mathrm{a}}$ & .559 & .515 & .84939
\end{tabular}

a.Predictors: (Constant), Size_QA, Kurs, DER, SBI, Inflasi_QA, Inflasi,

Kurs_QA, DER_QA, SBI_QA, Size

Dependent Variable: Yield to Maturity Source: Data processed

Based on the results of the statistics above, it can be seen the value of the coefficient of determination with an additional moderation variable of 0.515 or $51.5 \%$ while $48.5 \%$ is very efective, but the independent variables and interactions in the research model are only able to explain the dependent variable of 0.559 or $55.9 \%$ while $44.1 \%$ is explained by other variables not included Research Model.

\section{MRA Analysis}

MRA analysis is a special application of multiple linear regression to determine the relationship between two variables that are influenced by a third variable or a moderating variable. In the analysis technique Moderated Regression Analysis contains elements of interaction (multiplication of two or more independent variables). 
The results obtained after the data is processed with the help of the program can be

presented in the following table:

Table 7 Result Of Mra Method Regression Test

\begin{tabular}{|c|c|c|c|c|c|c|}
\hline \multirow[t]{2}{*}{ Model } & \multicolumn{3}{|c|}{ Unstandardized Coefficients } & \multirow{2}{*}{$\begin{array}{c}\begin{array}{c}\text { Stand } \\
\text { ardize } \\
\mathbf{d}\end{array} \\
\text { Coeffi } \\
\text { cients }\end{array}$} & \multirow[t]{2}{*}{$\mathbf{t}$} & \multirow[t]{2}{*}{ Sig. } \\
\hline & & & $\begin{array}{l}\text { Std. } \\
\text { Error }\end{array}$ & & & \\
\hline \multirow[t]{11}{*}{1} & (Constant) & 10.251 & 2.966 & & 3.456 & .001 \\
\hline & Exchange Rate & $5.514 \mathrm{E}-5$ & .000 & .022 & .259 & .796 \\
\hline & Exchange Rate_QA & .000 & .000 & -.917 & -2.756 & .007 \\
\hline & Inflation & .135 & .128 & .140 & 1.053 & .295 \\
\hline & Inflation_QA & -.113 & .149 & -.146 & -.757 & .451 \\
\hline & SBI & .218 & .177 & .213 & 1.229 & .222 \\
\hline & SBI_QA & -.002 & .193 & -.004 & -.010 & .992 \\
\hline & DER & -.072 & .068 & -.173 & -1.061 & .291 \\
\hline & DER_QA & .096 & .077 & .251 & 1.256 & .212 \\
\hline & Size & $\begin{array}{r}-7.395 \mathrm{E}- \\
8\end{array}$ & .000 & $\begin{array}{r}- \\
25.57 \\
0\end{array}$ & -5.276 & .000 \\
\hline & Size_QA & $7.362 \mathrm{E}-8$ & .000 & $\begin{array}{r}25.59 \\
0\end{array}$ & 5.256 & .000 \\
\hline
\end{tabular}

Source: Data processed

The results of the constant value of 10.251 which means that if the exchange rate, the exchange rate is moderated by audit quality (Exchange Rate_QA), inflation, inflation is moderated by audit quality (inflation_QA), BI interest rate (SBI), BI interest rate is moderated by audit quality (SBI_QA), DER, DER is moderated by quality audit (DER_QA), company size (size), company size is moderated by audit quality (size_QA) the result value is 0 . Then the yield to maturity has a positive value of 10.251 .

a) Where an increase of 1 unit variable exchange rate causes an increase of 5,514 variable yield to maturity (YTM) if the other variables are constant. The exchange rate against $\mathrm{YTM}=0.796>0.05$ and the value of $\mathrm{t}$ arithmetic $0.259<1.984$ conclusion: insignificant, $\mathrm{H} 1$ : Exchange rates have no effect on yield to maturity (YTM).

b) Where an increase in 1 unit of variable exchange rate is moderated by audit quality (Exchange Rate_QA) causes an increase of 0,000 variable QA if other variables are constant. Exchange Rate_QA to YTM $=0.007$ and $\mathrm{t}$ count value 2.998> 1.984 conclusion: significant, H2: QA_ rate affects the yield to maturity (YTM) but tends to be negative.

c) Where an increase of 1 unit variable inflation causes an increase of 0.135 yield to maturity (YTM) variable if the other variables are constant. Inflation on YTM $=0.295$ and $t$ count value of $1.053<1.984$ conclusion: insignificant, $\mathrm{H} 3$ : the 
exchange rate has no effect on yield to maturity (YTM).

d) Where an increase in 1 unit of inflation variable moderated by audit quality (inflation_QA) causes a decrease of 0.113 QA variable if the other variables are constant. Inflasi_QA against YTM = 0.451 and $-0.757 \mathrm{t}$ value $<1.984$ conclusion: not significant, H4: inflation _QA no effect on the yield to maturity (YTM).

e) Where an increase of 1 unit of the BI interest rate ( SBI ) causes an increase of 0.218 yield to maturity (YTM) variable if the other variables are constant. SBI against $\mathrm{YTM}=0.222$ and $\mathrm{t}$ count value $1.222<1.984$ conclusion: not significant, H5: SBI has no effect on yield to maturity (YTM).

f) Where an increase of 1 unit of the BI interest rate variable is moderated by audit quality (SBI_QA) causing a decrease of 0.002 QA variable if the other variables are constant. SBI_QA to YTM $=0.992$ and $\mathrm{t}$ count $-0.010<1.984$ conclusion: insignificant, H6: SBI_QA has no effect on yield to maturity (YTM).

g) Where an increase in 1 unit of the DER variable causes a decrease of 0.072 yield to maturity (YTM) variable if the other variables are constant. DER to YTM = 0.291 and $\mathrm{t}$ count $-1.061<1.984$ conclusion: not significant, H7: DER has no effect on yield to maturity (YTM).

h) Where an increase in 1 unit of the DER variable is moderated by audit quality (DER_QA) causing an increase of 0.096 QA variable if the other variables are constant. DER_QA to YTM $=0.212$ and $\mathrm{t}$ count $1.256<1.984$ conclusion: not significant, H8: DER_QA has no effect on yield to maturity (YTM).

i) Where an increase in 1 unit of the firm size variable (Size) causes a decrease of 7.395 variable yield to maturity (YTM) if the other variables are constant. Size to $\mathrm{YTM}=0,000$ and $\mathrm{t}$ count value of 5.276> 1.984 conclusion: significant, H9: Size affects the yield to maturity (YTM) but tends to be negative. j) Where an increase of 1 unit of variable firm size is moderated by audit quality (size_QA) causing an increase of 7,362 QA variables if the other variables are constant. Size_QA to YTM $=0,000$ and $t$ count value of 5.256> 1.984 conclusion: significant, H10: size_QA affects the yield to maturity (YTM).

\section{CONCLUSION}

This study aims to determine and analyze the effect of exchange rates, inflation, BI interest rates, Debt to Equity Ratio, and company size on yield to maturity obstruction with audit quality as a moderating variable. From these results it can be concluded:

a) The exchange rate (exchange rate) of the rupiah against the dollar is not significant to the yield to bond maturity. The conclusion is that the higher the exchange rate to be charged will not affect the results obtained, especially the return from yield to maturity of the bond itself.

b) Exchange rate moderated by audit quality (Exchange Rate_QA) has an effect on yield to maturity. Analysis before moderation has no effect and after moderation becomes influential, which explains that the pure moderation variable is strengthening.

c) Inflation has no effect on yield to bond maturity. The inflation hypothesis does not affect the yield to bond maturity, so that the more inflation the country gets, it will not have an impact on the return of return, especially by testing the yield to maturity of the bond.

d) Inflation moderated by audit quality (Inflation_QA) on yield to maturity has no effect. Explain the effect and role of audit control on inflation in increasing yields in the form of yield to maturity.

e) BI interest rates have no effect on bond yields until maturity. Explain that the 
high $\mathrm{BI}$ interest rate that is set will not affect the return on yields to maturity of the bonds.

f) BI interest rates, if moderated by audit quality, will not affect the yield to bond maturity. Explaining that the high BI interest rate that is set will not affect the rate of return on yield until the bond matures.

g) The ratio of debt to yield to bond maturity is not significant and has no effect, explaining that the ratio of debt to equity in reporting will not affect the yield to maturity of bonds.

h) The ratio of debt moderated by audit quality to yield to bond maturity is not significant and has no effect, explaining that the ratio of debt moderated to equity in reporting will not affect bond yield to maturity.

i) Company size on bond yield to maturity explains that research has a negative and significant effect on bond yield to maturity, this explains that the higher the size of the company in total assets will have an effect on the return of yield on bond maturity.

j) Company size moderated by audit quality on bond yields to maturity explains that this research has a positive and significant effect on bond yields to maturity, this explains that the higher the size of the company's total assets will affect the return.

\section{Suggestion}

Based on the results of the study there are several suggestions for improvement of similar research in the future, namely:

1) For further research, it is expected to use variables outside the studied variables.

2) Further researching yield to maturity by moderation or mediation by audit quality (by nominal use or calculation).

3) In moderation it is recommended not to use dummy.
4) Using more samples than the samples used by the present study.

For further research, it is better to be able to conduct research for other types of categories to determine returns other than yield to maturity methods.

\section{REFERENCE}

Agoes, S. (2017). Auditing Petunjuk Praktis Pemeriksaan Akuntan oleh Akuntan Publik. In 1 .

Ang, A., \& Sherris, M. (1997). Interest rate risk management: Developments in interest rate term structure modeling for risk management and valuation of interest-rate-dependent cash flows. North American Actuarial Journal. https://doi.org/10.1080/10920277.1997.1059 5601

Black, H. A., Fabozzi, F. J., \& Modigliani, F. (1992). Capital Markets: Institutions and Instruments. The Journal of Finance. https://doi.org/10.2307/2329011

Francis, J., \& Schipper, K. (1999). Have Financial Statements Lost Their Relevance? Journal of Accounting Research. https://doi.org/10.2307/2491412

Hamid, Abdul, Rodon, Ahmad, W, Dewi Titi dan Hidayat, E. (2006). Analisis Durasi Dan Convexity Untuk Mengukur Sensitivitas Harga Obligasi Korporasi Terhadap Perubahan Tingkat Suku Bunga (Studi Empiris Pada Obligasi-Obligasi Di Indonesia). Jurnal Manajemen, Akuntansi \& Sistem Informasi.

Hapsari, R. A., \& Artikel, I. (2013). Kajian Yield To Maturity (Ytm) Obligasi Pada Perusahaan Korporasi. Accounting Analysis Journal, 2(1). https://doi.org/10.15294/aaj.v2i1.1152

Hartono, Musakini, J. (2014). Analisis \& Desain Sistem Informasi Sitem Informasi: Pendekatan terstruktur teori dan praktik aplikasi bisnis. In Analisis \& Desain Sistem Informasi Sitem Informasi: Pendekatan terstruktur teori dan praktik aplikasi bisnis. https://doi.org/10.1002/ange.200803496

Ibrahim, H., \& C4a006286, N. (2004). Program Studi Magister Manajemen Program Pasca Sarjana Universitas Diponegoro Semarang 2008 .

Kuswadi. (2005). Meningkatkan Laba Melalui Pendekatan Akuntansi dan Keuangan Biaya. (Jakarta: PT Elexmedia Komputindo). Hal 88.

Laksmono R, D., Suhaedi, S., Kusmiarso, B., I, A., 
Pramono, B., Hutapea, E. G., \& Pambudi, S. (2003). Suku Bunga Sebagai Salah Satu Indikator Ekspektasi Inflasi. Buletin Ekonomi Moneter Dan Perbankan. https://doi.org/10.21098/bemp.v2i4.283

Listiawati, L. N., \& Paramita, V. S. (2018). Pengaruh Tingkat Suku Bunga, Inflasi, Debt To Equity Ratio , Dan Ukuran Perusahaan Terhadap Yield Obligasi Pada. Jurnal Manajemen, 15(1), 33-51.

Machfoedz, M. (1994). Financial Ratio Analysis and the Prediction of Earning Changes in Indonesia. In Kelola.

Mishkin, F. S. (2007). The economics of money, banking, and financial markets. In Policy.

Nabiu, M., Yuliarti, E., \& Manurung, E. (2006). Analisis Nilai Tambah Dan Kemampulabaan Tiga Agroindustri Vco D1 Kota Bengkulu. Jurnal AGRISEP. https://doi.org/10.31186/jagrisep.5.1.53-62

Nariman, A. (2017). Pengaruh Faktor Internal Dan Eksternal Perusahaan Terhadap Yield To Maturity Obligasi Korporasi Yang Terdaftar Di Bursa Efek Indonesia. Jurnal Akuntansi, 20(2), 238 . https://doi.org/10.24912/ja.v20i2.56

Neimark, M. K. (1994). Regicide Revisited: Marx, Foucault and Accounting. Critical Perspectives on Accounting. https://doi.org/10.1006/cpac.1994.1005

Noviana, L., \& Solovida, G. T. (2018). Pengaruh Likuiditas , Leverage, Rating Obligasi Syariah , Risiko Obligasi Syariah Terhadap Yield Obligasi Syariah (Sukuk). Stability: Journal of Management and Business, 1(2), 171-188. https://doi.org/10.26877/sta.v1i2.3226

Rahman, A. A., \& Sam'ani. (2013). Analisis Faktor-Faktor Yang Mempengaruhi Yield Obligasi Negara Tahun 2010 - 2012. Jurnal Komunikasi Penelitian, 16(1), 38-46.

Samsul, M. (2006). Pasar modal dan manajemen portofolio. In Jakarta: Erlangga. https://doi.org/10.22236/agregat

Saputra, T. A. (2014). Analisis Faktor-Faktor Yang Mempengaruhi Yield Obligasi Konvensional Di Indonesia(Studi Kasus Pada Perusahaan Listed di BEI). 11(1), 6777.

https://doi.org/10.14710/jsmo.v11i1.13163

Sawir, A. (2012). Analisis Kinerja Keuangan dan Perencanaan Keuangan Perusahaan. PT Gramedia Pustaka Utama. https://doi.org/10.1021/j100193a062

Statement of Financial Accounting Concept (SFAC) No. 1. (1978). 93(11), 61-67.

Suharti, L., \& Sirine, H. (2012). Faktor-Faktor yang Berpengaruh Terhadap Niat Kewirausahaan (Entrepreneurial Intention). Jurnal Manajemen Dan Kewirausahaan. https://doi.org/10.9744/jmk.13.2.124-134

Sunariyah. (2013). Pengantar Pengetahuan Pasar Modal. Penerbit: UPP STIM YKPN, Yogyakarta.

https://doi.org/10.1093/bioinformatics/btk04 5

Tjandrasa, B. B. (2017). The Effect of Consumer Expectation Index, Economic Condition Index and Crude Oil Price on Indonesian Government Bond Yield. Journal of Economics, Business \& Accountancy Ventura, 20(1), 1. https://doi.org/10.14414/jebav.v20i1.935

Vose, D. (1996). Quantitative Risk Analysis: A Guide to Monte Carlo Simulation Modeling. $L E V$.

Watts, R., \& Zimmerman, J. (2006). Positive Accounting Theory: A Ten Year Perspective. Accounting Review. 